\title{
金をベースとするナノ粒子を俯瞰する \\ Overlook of Gold Nanoparticles and Other Metal Nanoparticles Containing Gold
}

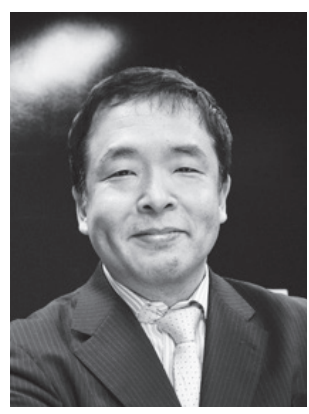

米澤 徹

北海道大学 大学院工学研究院 材料科学部門

于 060-8628

北海道札幌市北区北十三条西 8 丁目

Tetsu YONEZAWA

Division of Materials Science and Engineering,

Faculty of Engineering, Hokkaido University

Kita 13 Nishi 8, Kita-ku, Sapporo, Hokkaido

060-8628, Japan

論文要旨：金ナノ粒子は，その興味深い赤色から古くから着色顔料として用いられてきている。古い教会 のステンドグラスはガラスの中で金がナノ粒子として存在しているもので, 透明性が高く鮮やかな赤色を示 している。金ナノ粒子の化学的研究の歴史も古く 1857 年に文献にある Faraday の金コロイドの合成から始 まる ${ }^{1,2)}$ 。金それ自体は古くから価值のあるものとして用いられてきており，バルクでは鮮やかな黄金色で あるが，その色とコロイドにした時の色は全く異なっていた。そうした直接目に見える興味深い現象から始 まって, 金ナノ粒子は常に人々の興味の中心となってきた。特に, 化学還元法で容易に得られることも研究 がこれだけ進んだことの理由でもあろう。さらに, Brustらによるシングルナノレベルの金ナノ粒子の合成 が $\mathrm{NaBH}_{4}$ による還元によって可能となってきてから爆発的な量の研究が報告されるとともに, 一段と金ナ ノ粒子研究のステージは上がった ${ }^{3)}$ 。最近の制御された金クラスターや新しい触媒など, 金は人々の興味を 掻き立てるのをやめない。この総説ではそうした金をべースとしたナノ粒子研究を俯瞰し, 人々がひきつけ られていく原因を探ってみたい。

\begin{abstract}
Gold nanoparticles have been widely used as a good inorganic red pigment which show dark wine red color. Gold nanoparticles are considered as a long life pigment. Red stained glasses often used in old churches are old glasses containing gold nanoparticles. They are very clear and show dark red color. The history of the chemistry of gold nanoparticles is very long, and began in 1857 . Faraday firstly reported the preparation of red gold hydrosol ${ }^{1,2)}$. Gold itself is a highly precious materials and show brilliant gold luster. However, gold nanoparticles show considerably different color. Gold has attracted much interest not only from scientists. Such gold nanoparticles can be prepared quite readily by chemical reduction of the corresponding salts, which also support their intensive scientific studies. Recently, Brust et al. reported the preparation of single nanometer-sized gold nanoparticles by $\mathrm{NaBH}_{4}$ reduction ${ }^{3)}$. This pioneering report introduced explosive expansion of nanoparticle researches. Gold nanoclusters and gold nanocatalysts which are also invented quite recently still continue to attract the peoples' interest. In this section, I would like to overlook the studies of gold nanoparticles.
\end{abstract}

Key words: gold, nanoparticle, nanocluster, catalysis, electroconductive, fluorescence

\section{1 はじめに}

金属ナノ粒子の研究は様々な金属を用いて盛んに行わ れている ${ }^{4-9)}$ れその中で, 今回の特集では, お二人の著

連絡者: 米澤 徹

E-mail : tetsu@eng.hokudai.ac.jp
名な研究者の方が金ナノ粒子の魅力について語られてい る。私は，金だけをターゲットとして研究を行っている 研究者ではないが, やはり金のナノ粒子には常に興味を もってみてきた。比較的大きな金ナノ粒子は, そのプラ ズモン吸収による赤色を呈し, それは有機顔料とは比べ 物にならないほど長期間その鮮やかな色を保っている。 
このプラズモン吸収はその極大波長が粒子径によって変 化し，また凝集形態，形状によっても大きく変化し，こう した変化がセンシングに用いられていることも多い ${ }^{10)}$ 。 実際に，たとえば生体関連物質や組織の透過型電子顕微 鏡観察に扔ける染色材料としても用いられているほか, 特定のタンパクやウイルスの検出のためのイムノクロマ トグラフィーに応用されていると聞く ${ }^{11}$ 。

金, 銀, 銅のナノ粒子は可視光にこうしたプラズモン 吸収ピークの極大があり，見た目にも色がついている。 金と銅は深みのある赤色，銀は黄色を示すことがよく知 られている。これらの色は，金属の色となるため，有機 顔料のような退色を防ぐことが可能となっている。また, 研究を進めていくと色だけでもナノ粒子の出来の良しあ しがわかってくるようにもなる。

こうしたプラズモン吸収を示すナノ粒子は比較的大き く, 数 $\mathrm{nm}$ 以上 $100 \mathrm{~nm}$ 以下の大きさである。大きい粒 子のほうが吸光係数が高く, 色が濃く見える。一方で, 非常に微細なシングルナノレベルのナノ粒子はこうした プラズモン吸収を見せなくなってくる。こうした微細な ナノ粒子もプラズモン吸収を示す比較的大きなナノ粒子 と同様の化学還元法で得られるほか，スパッタリング法 によっても容易に合成できる。ナノ粒子の粒子径・構造 の制御がテクニックの見せ所となっている。

このようにして得られた非常に微細な金ナノ粒子は, プラズモン吸収を示すような大きな金ナノ粒子では示さ ない高い触媒活性を示すことが最近の研究からわかって きた。さらには，量子サイズ効果によってバンドギャッ プの広がりから金属の特徵を失って, 蛍光を発光するよ うになる。さらには，焼結しなくても導電性を示す金ナ ノ粒子も得られるようになってきた。金はこのようにナ ノサイズ化するとその大きさや形状によって大きく性質
を変化させることは非常に化学者・技術者の興味を深く させる。

そこで，本小文では，こうした金をべースとするナノ 粒子の研究のうち, 特に触媒, 蛍光性ナノ粒子材料, 導 電性材料に関する研究について俯瞰してみることにす る。

\section{2 触媒としての金ナノ粒子}

触媒としての金は，現首都大学東京の春田正毅教授が 見出したもので，金を小さなクラスターとし，酸化物に 担持させると高機能触媒となる。金は従来，それ自身が 安定であるために貴金属として重用されてきているので あるが，それが触媒活性を有するとは考えられていな かった。しかしこれまで小さなナノ粒子が合成できな かったが，Brustらがチオールを用いて $\mathrm{NaBH}_{4}$ で還元 することによりシングルナノレベルの微細なナノ粒子の 合成が可能となった $(\text { Fig. 1 })^{3)}$ 。そののち, 膨大の研究 が短期間のうちになされ，金ナノ粒子は非常に重要な材 料に変わった。一つは，金ナノ粒子表面に有機物によっ て機能性化合物を修飾し，金ナノ粒子に新しい機能を持 たせるような研究も広く行われた。一方で，金それ自体 が微細化したために発現した性質を用いた研究も多く行 われてきた。そのひとつが，触媒である。

春田らは，塩化金酸を原料とし，その水溶液の $\mathrm{pH}$ を 制御して水酸化金（III）を発生させて還元しやすくして ナノ粒子を合成し担持させて，非常に微細な金ナノ粒子 酸化物担持触媒の製造に成功した。

こうした微細な金ナノ粒子をチタニアに担持させて世界 に先駆け高機能な CO 酸化触媒となることを示された ${ }^{12}$ 。 チタニアやセリアに担持された金ナノ粒子は，それらに 担持されたパラジウムに比べても触媒活性が高いことが
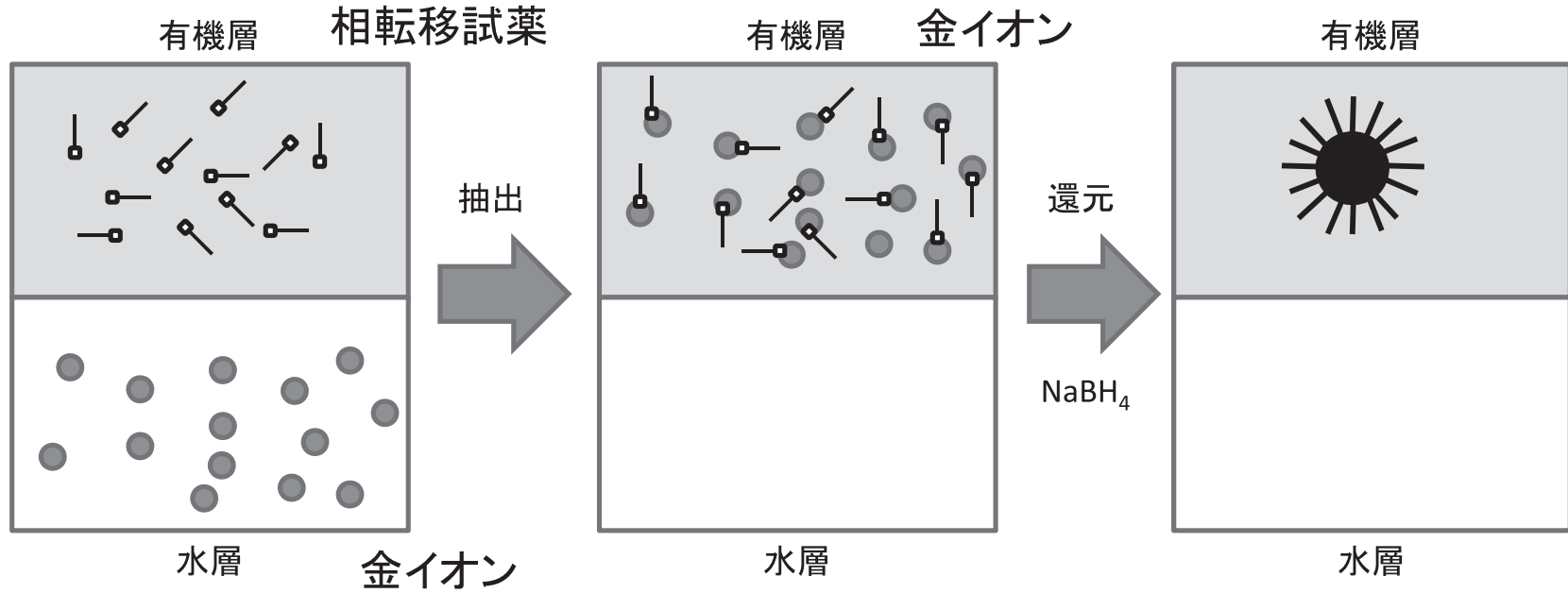

Fig. 1 Brustらの開発したチオール保護金ナノ粒子の製造法。塩化金酸イオンを疎水相に界面活性剂で移し，そのあとに水素化 ホウ素ナトリウム溶液を与えて還元させる。微細で粒子径の揃ったナノ粒子を合成できる ${ }^{3)}$ 。 
示されている。さらには，金チタニア系触媒によるプロ ピレンの直接酸化反応に扔いては, 粒子径と反応生成物 とに相関があることがわかった。例えば，粒径が $5 \mathrm{~nm}$ 以上のものであれば，プロパンが生成してしまうが, $5 \mathrm{~nm}$ 以下の粒子径を持つ金ナノ粒子を用いれば，プロ ピレンオキサイドが得られ， $100^{\circ} \mathrm{C}$ という低温でその反 応は進むことが明らかとなっている ${ }^{13)}$ 。金ナノ粒子は 酸化触媒に限らず，選択的水素化反応に扔いても威力を 発揮する。例えば，ニトロベンゼン誘導体のアミノベン ゼンへの選択的水素化反応では, パラジウムを用いれば, ニトロ基だけでなく $\mathrm{C}=\mathrm{C}$ 結合, $\mathrm{C}=\mathrm{O}$ 結合の水素化が 起きるが，金チ夕ニア触媒ではニトロ基のみが水素化さ れていく ${ }^{14)}$ ここうした金チタニア系触媒では, STEMHAADF 観察によって原子分解能の像をえて, 金一チ夕 ニア，また金一セリアの原子間の距離を評価するなど， 微細形状の検討がなされている ${ }^{15-17)}$ 。また，チ夕ニア 単結晶基板上に金ナノ粒子を堆積させ，金ナノ粒子/金 属酸化物のモデル触媒を作製して, CO の吸着特性や酸 化反応の詳細も検討されている。

一方で，PVPに保護された金ナノ粒子など，非担持 系金ナノ粒子も触媒として有効であることが示された。 PVPに保護された金ナノ粒子は水分散状態で常温でア ルコール酸化反応などに優れた活性を示すことが明らか となっている ${ }^{18)}$ 。この場合でも $5 \mathrm{~nm}$ 以下の金ナノ粒子 に高活性であることが示されている ${ }^{19)}$ 。

金とパラジウムの合金ナノ粒子を PVP 保護によって アルコール還元で合成すると，金ナノ粒子のみよりも ずっと小さな粒子が合成できる。このナノ粒子は，Pd がシェルで Auがコアの構造を有しており，水素化反応 に高活性である ${ }^{20)}$ 。また，逆形状の $\mathrm{Au}$ シェル，Pd コ ア構造をもつナノ粒子も水素化触媒として有効であるこ とが示されている ${ }^{21)}$ 。また，金と白金の合金ナノ粒子 も PVP 保護によって合成でき, 可視光誘起光水素化反 応の良好な触媒となることが示されている。 $\mathrm{Au} / \mathrm{Pt}$ ノ粒子も Ptがシェル，AuがコアだとXPS から判断さ

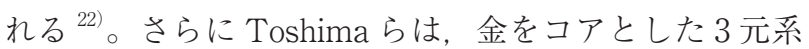
のナノ粒子触媒の開発も行い, 成果を得ている ${ }^{23)}$ 。

さらに進んだ触媒が最近見いだされた。これはパラジ ウムからなるナノ粒子の頂点に金原子を置いた粒子であ る。パラジウム原子 135 個に金 12 個からなる。これが グルコースの空気酸化に最も高い活性を示した。Fig. 2 のような触媒でクラウンジュエル触媒と名付けられた ${ }^{24)}$ 。

このように，金はナノ粒子化・原子状にすることで非 常に高活性な触媒として機能することが示された。また， 他の元素の触媒機能をアシストすることも見出されてい る。金の価格は白金族の元素の価格よりも安い場合があ

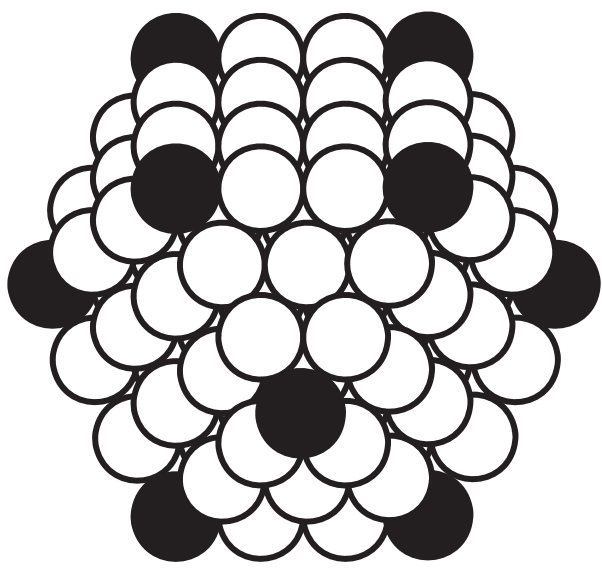

Fig. 2 Toshima らの開発したクラウンジュエル触媒。特定 のサイトに金原子があり,これが高活性の要因であ る $^{24)}$ 。

り，元素代替の一例としても評価を受けるべきである。

\section{3 導電性ナノ粒子としての金}

金表面には原子のゆらぎがあることが知られている。 金ナノ粒子の表面は柔らかく, 電子顕微鏡で観察した時 には比較的原子量の大きな元素であるにもかかわらず, 原子像が見えにくいことが知られている。金はバルクで も柔らかく，容易に延ばすことができ，たとえば金䇴な ども生産されている。こうしてみると, 金ナノ粒子は, さらに融点が低下する可能性があるのだから, 容易に低 温で焼結できるのではないかと期待される。こうした現 象を利用した導電性材料としての金が興味深い。

たとえば，筆者らは様々なカチオン性の保護剂で保護 した金ナノ粒子を合成したが，それらのうち，チオコリ ンブロミド $\left(\mathrm{HS}\left(\mathrm{CH}_{2}\right)_{2} \mathrm{~N}\left(\mathrm{CH}_{3}\right)_{3} \mathrm{Br}^{-}\right)$によって保護さ れた金ナノ粒子を合成した。こうした 4 級アンモニウム 塩によって保護された金ナノ粒子は，反対電荷をもった 高分子の上に密に吸着することがわかっている。一般的 に，こうした小さなリガンドで保護した場合でも，微粒 子同士はリガンドの長さの 2 倍程度の長さだけ離れて パッキングするはずである。しかしながら，チオコリン ブロミドで保護された金ナノ粒子だけは，常温でナノ粒 子が融合し，数珠つなぎになるのである (Fig. 3 $)^{25)}$ 。こ れは，金表面の原子が摇らいでいることと関連している と考えられる。

このような性質は導電性インクとしての金につながっ ていくと考えられる。実際に, Satoらは, メルカプト コハク酸を用い, $\mathrm{NaBH}_{4}$ で還元して合成した微細な金 ナノ粒子 ${ }^{26)}$ を超音波照射によって粗大化し， $18 \mathrm{~nm} の$ 平均粒径を有したものを作製した。こうして得られた金 ナノ粒子を分散・インク化して印刷・塗布ののち蒸発さ 


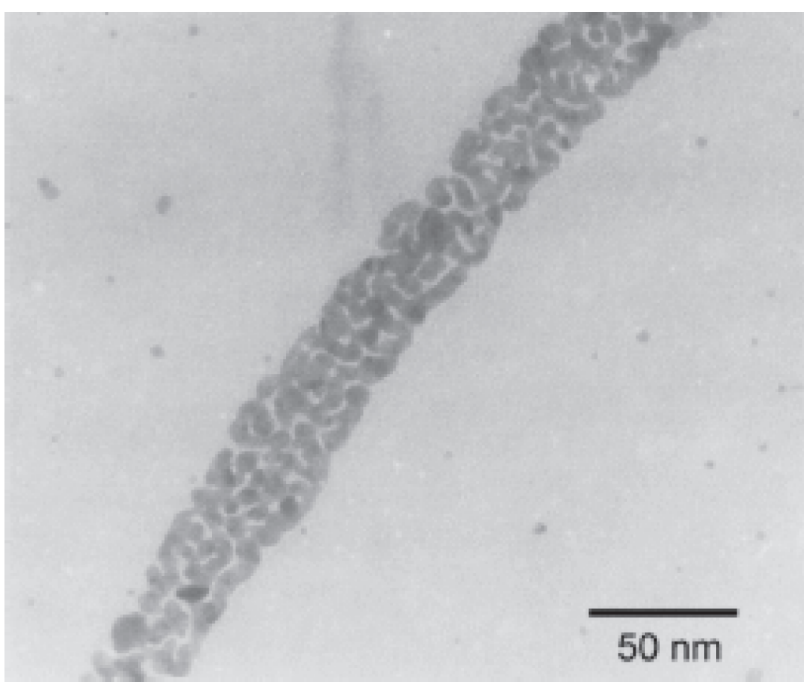

Fig. 3 チオコリンブロミドで合成した金ナノ粒子をDNA 上に吸着し配列させたあとの TEM 像。金ナノ粒子 が部分的に融合していることがわかる（Reprinted with permission from the Reference 25. Copyright 2002 The Chemical Society of Japan)。

せると金色の膜ができることを報告している。このよう にある程度大きな金ナノ粒子を小さな分子保護剤でコー ティングした時，金光沢を示す膜が生成し，導電性を示 すことがある。こうして得られた膜は，比較的高い導電 性を示すとされる ${ }^{27)}$

一方で，保護剤に工夫をして導電性を持たせた例もあ る。Kanehara らは室温で導電性をもつ金ナノ粒子をフ タノシアニン類縁体でコートすることで，その $\pi$ 共役 性を利用して導電性をもつと主張している ${ }^{28)}$ 。

いずれにせよ，金ナノ粒子を密に接することによって 導電性をもった素材にすることは十分に可能であること がこれらの例からも期待される。金はコストが高いとさ れるが，銀の持つマイグレーション性の問題や，銅が容 易に酸化され安定なナ八粒子を得にくいという問題点の 解決にはまだまだコストが必要であり，金を利用する可 能性はまだ十分に残されていると考えられる。

\section{4 蛍光を示す金ナノ粒子}

金属であっても，非常に小さくし，原子が数個〜数十 個程度にしてしまうと半導体のような振る舞いを示す。 それがいわゆる量子サイズ効果，久保効果といわれるも のである。そのため,こうした金属ナノ粒子は量子ドッ トのような光学特性を示す可能性がある。金であっても 同様であると考えられ，そのサイズに依存する吸光・発 光特性を示しうる。金属ナノ粒子，特に金ナノ粒子は, $\mathrm{CdS}$ などの半導体量子ドットに比べ，細胞毒性が低い と考えられ，新しい生体分子の可視化ツールとして期待 される。
非常に小さく合成された金ナノ粒子は，量子サイズ効 果によってそのバンドギャップが徐々に大きくなる。そ れが金ナノ粒子発光の起源となりうる。触媒の欄でも述 べた通り, $\mathrm{NaBH}_{4}$ 還元法とチオールの組み合わせは Brustによりシングルナノのレベルのナノ粒子を得る方 法として発表され ${ }^{3)}$, それらが改良されてさらに微細ナ ノ粒子が得られるようになった。特に, 昨今のチオール 保護金ナノ粒子は $2 \mathrm{~nm}$ 程度以下のものが合成できるよ うになっており,こうした特徴をもつ金ナノ粒子の出現 を期待することができる。

Wang らは， $\mathrm{NaBH}_{4}$ を用いた化学還元法によって， 微細な金ナノ粒子を合成した。様々なチオールを用いて 金ナノ粒子を合成し，それらは粒子径が $1.1 \mathrm{~nm}$ 程度で あった $\left(\mathrm{Au}_{38}\right)$ 。これらの金ナノ粒子は近赤外領域に蛍 光発光を示すことが明らかとなっている ${ }^{29)}$ 。さらに Negishi らは，さらに小さな金ナノ粒子（次節で述べる 金ナノクラスター）を合成している。それらを分画する ことで, その吸収执よび蛍光特性の評価を行っている ${ }^{30)}$ 。

我々は，マトリクススパッタリング法というマグネト ロンスパッ夕を利用し，チオール液体中に金をスパッ夕 することで金ナノ粒子を作製した ${ }^{31,32)}$ 。つまり上記の 2 つの論文とは異なり，金属から直接ナノ粒子を合成し ている。粘度の高い液状のモノマー内でナノ粒子を合成 することで容易に熱硬化性樹脂内に蛍光性金ナノ粒子を 取り达むことに成功した ${ }^{31)}$ ほか，同様にマトリクスス パッタリング法によって合成されたカチオン性チオール に保護された金ナノ粒子も同様に蛍光を発した ${ }^{32)}$ 。そ の金ナノ粒子は，近赤外に発光を示すが，大きなストー クシフトを示すことが明らかとなっている。

このように，合成法，周囲にある保護剤（リガンド） を制御することによって，大きさのみならず蛍光特性の チューニングが可能であることは非常に興味深いといえ る。

\section{5 構造が詳細に理解されている金ナノクラスター}

金ナノ粒子の研究はさらに進んでいる。金属錯体的な 手法やエッチングの手法によって原子数を決定した金ナ ノクラスターを得ることが可能である。さらには, ゲル 電気泳動やサイズ排除体積クロマトグラフィーなどを用 いてナノ粒子のサイズによる分画をすることで，所望の サイズのナノ粒子を得ることが可能である。その中でも $\mathrm{Au}_{25}$ は, よく合成される魔法数の金ナノクラスターで ある。これらの原子数が明確に測定できるレベルの金ナ ノクラスターは, 透過型電子顕微鏡（TEM）のみならず, 質量分析（MS）によってその原子数を算出している。 質量分析のイオン化法には，比較的大きな分子量が測定 


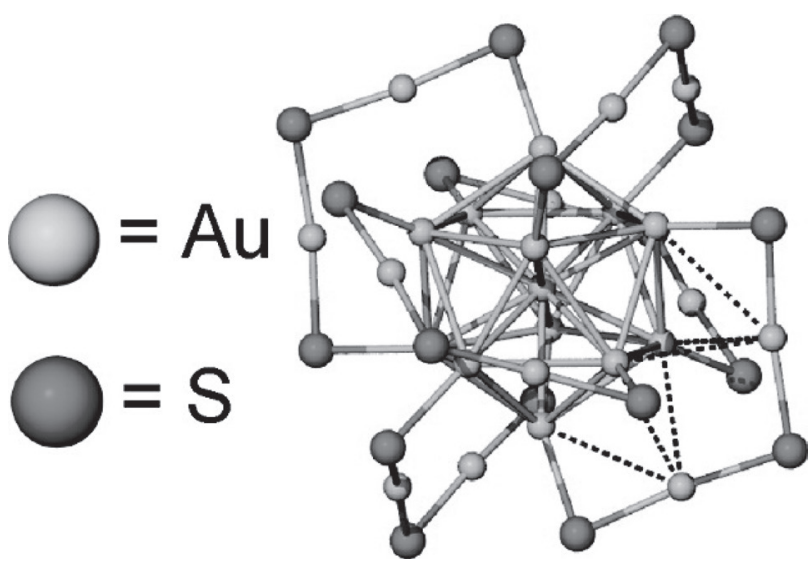

Fig. $4 \mathrm{Au}_{25}\left(\mathrm{SCH}_{2} \mathrm{CH}_{2} \mathrm{Ph}\right)_{18}$ クラスターの構造の図 (Reprinted with permission from M. W. Heaven, A. Dass, P. S. White, K. M. Holt, and R. W. Murray, Crystal Structure of the Gold Nanoparticle $\left[\mathrm{N}\left(\mathrm{C}_{8} \mathrm{H}_{17}\right)_{4}\right]\left[\mathrm{Au}_{25}\right.$ $\left.\left(\mathrm{SCH}_{2} \mathrm{CH}_{2} \mathrm{Ph}\right)_{18}\right]$, J. Am. Chem. Soc., 130, 3754 (2008). Copyright 2008 The American Chemical Society)。

できるエレクトロスプレーイオン化法や MALDI（マト リクス支援レーザー脱離イオン化法)が用いられている。

最近では適切な量の原子数の決定された金クラスター を合成・選別することも可能となっており, 単結晶を作 製し，そのX 線構造解析によって詳細な原子配列と保 護構造が明らかとなってきている。ステープル針のよう に-S-Au-S-Au-S-, -S-Au-S- 構造が表面を覆った $\mathrm{Au}_{\mathrm{m}} \mathrm{SR}_{\mathrm{n}}$ クラスターが提案されてきている ${ }^{33)}$ (Fig. 4)。こうした ナノクラスターでは原子数が 1 個変わるだけで, 特性を 大きく変化させることができることも明らかとなってき た。最近では，こうした原子数が決定した金ナノクラス ターに異種元素を導入する試みも行われている。

\section{6 おわりに}

金ナノ粒子は，従来の鮮やかな赤色を示すナノ粒子か らさらに詳細に検討されるようになり, 詳しい研究が広 く遂行されてきた。赤色がプラズモン吸収であることは ほかの章でも触れられているが, さらに微細なナノ粒子 がこれまでにない新しい特徴を示しうることがわかって きた。その例が触媒, 導電材料, 蛍光性ナノ粒子である。 金の安定性，生体親和性の高さは，こうした材料の応用 展開の手助けにもなっている。今後もさらに金ナノ粒子 の研究は大きく広がっていくことが強く期待できる。

\section{文 献}

1) M. Faraday, Philos. Trans. R. Soc. London, 147, 145 (1857).

2) M. Kerker, J. Colloid Interface Sci., 112, 302 (1986).

3) M. Brust, M. Walker, D. Bethell, D. J. Schiffrin, and R. Whyman, Chem. Commun., 801 (1994).
4) N. Toshima and T. Yonezawa, New J. Chem., 22, 1179 (1998).

5）高分子学会編，「微粒子・ナノ粒子」，共立出版（2012）.

6) 林真至編著,「ナノ粒子」, 近代科学社 (2013).

7）米澤徹監修,「金属ナノ・マイクロ粒子の形状・構造制 御技術」，シーエムシー出版 (2009).

8）米澤徹監修,「金属ナノ・マイクロ粒子の最新技術と応 用」, シーエムシー出版 (2013).

9）西信之, 佃達哉, 斉藤真司, 矢ケ崎环磨, 「クラスター の科学」, 米田出版 (2009).

10）三浦佳子, 米澤徹, Dojin News, 113, 1 （2005）.

11）石原一彦, 畑中研一, 山岡哲二, 大矢裕一, 「バイオマ テリアルサイエンス」, 東京化学同人 (2003).

12) M. Haruta, T. Kobayashi, H. Sano, and N. Yamada, Chem. Lett., 405 (1987).

13) C. Qi, J. Huang, S. Bao, H. Su, T. Akita, and M. Haruta, J. Catal., 281, 12 (2011).

14) A. Corma and P. Serna, Science, 313, 332 (2006).

15) T. Akita, K. Tanaka, M. Kohyama, and M. Haruta, MRS Symp. Proc., 1026, C17-14 (2008).

16) T. Akita, K. Tanaka, M. Kohyama, and M. Haruta, Surf. Interface Anal., 40, 1760 (2008).

17) T. Akita, K. Tanaka, and M. Kohyama, J. Mater. Sci., 43, 3917 (2008)

18) H. Tsunoyama, H. Sakurai, Y. Negishi, and T. Tsukuda, J. Am. Chem. Soc., 127, 9374 (2005).

19) H. Tsunoyama, H. Sakurai, and T. Tsukuda, Chem. Phys. Lett., 429, 528 (2006).

20) N. Toshima, M. Harada, Y. Yamazaki, and K. Asakura, J. Phys. Chem., 96, 9927 (1992).

21) Y. Shiraishi, D. Ikenaga, and N. Toshima, Aust. J. Chem., 56, 1025 (2003).

22) T. Yonezawa and N. Toshima, J. Mol. Catal., 83, 167 (1993).

23) N. Toshima, R. Ito, T. Matsushita, and Y. Shiraishi, Catal. Today, 122, 239 (2007).

24) H. Zhang, T. Watanabe, M. Okumura, M. Haruta, and N. Toshima, Nature Mater., 11, 49 (2012).

25) T. Yonezawa, S. Onoue, and N. Kimizuka, Chem. Lett., 2002, 1172.

26) T. Oonishi, S. Sato, H. Yao, K. Kimura, J. Appl. Phys., 2007, 101, 114314.

27) H. Yamauchi, T. Dobashi, and S. Sato, Chem. Lett., 2012, 41, 1154.

28) M. Kanehara, J. Takeya, T. Uemura, H. Murata, K. Takimiya, H. Sekine, and T. Teranishi, Bull. Chem. Soc. Jpn., 85, 957 (2012).

29) G. Wang, R. Guo, G. Kalyuzhny, J.-P. Choi, and R. W. Murray, J. Phys. Chem. B, 110, 20282 (2006).

30) Y. Negishi, K. Nobusada, and T. Tsukuda, J. Am. Chem. Soc., 127, 5261 (2005).

31) Y. Shishino, T. Yonezawa, K. Kawai, and H. Nishihara, Chem. Commun., 46, 7211 (2010).

32) Y. Shishino, T. Yonezawa, S. Udagawa, K. Hase, and H. Nishihara, Angew. Chem., 123, 729 (2011).

33) M. W. Heaven, A. Dass, P. S. White, K. M. Holt, and R. W. Murray, J. Am. Chem. Soc., 130, 3754 (2008). 